DePauw University

Scholarly and Creative Work from DePauw University

2-3-2017

\title{
Pedagogy and Politics, Confrontational Negotiations: A Response to Zhao
}

Derek R. Ford

DePauw University, derekford@depauw.edu

Follow this and additional works at: https://scholarship.depauw.edu/educ_facpubs

Part of the Education Commons

\section{Recommended Citation}

Ford, D.R. Stud Philos Educ (2017) 36: 225. doi:10.1007/s11217-016-9547-y The final publication is available at Springer via http://dx.doi.org/10.1007/s11217-016-9547-y

This Article is brought to you for free and open access by the Education Studies at Scholarly and Creative Work from DePauw University. It has been accepted for inclusion in Education Studies Faculty publications by an authorized administrator of Scholarly and Creative Work from DePauw University. 


\title{
Pedagogy and politics, confrontational negotiations: A response to Zhao
}

\author{
Derek R. Ford \\ derekford@depauw.edu \\ DePauw University, Greencastle, IN, USA
}

The encounter always necessarily entails a certain risk and disruption. It's the shock of nonsovereignty and non-identity. And if there is anything that capitalism and democracy can't tolerate, it's risk. That's why liberal democracies try to reduce the chances for the encounter in every instance, ordering identities and spaces in particular ways, prescribing and policing the modes and rules of intercourse and exchange. You are free - encouraged, even - to disagree, to protest, so long as you do so in accordance with our modes of disagreement and protest. The purpose of dialogue here is one of clarification: to persuade or to shore up differences, or, what amounts to the same thing, to clear up what is at stake. All of that is important, too, but the encounter can't be reduced to dialogue, or even communication. I'm obliged to Weili Zhao for her engagement with my book, an engagement I would refer to not as a review but as the actualized product of an encounter, one that keeps the unbearable impossibility of translation in play. If there is a score, then it is one to be orchestrated and performed, not settled.

It's a document that has allowed me, or, better, pushed me, to become blind to my own words, and that is a real gift. But like any gift, the document has its demands. No one, after all, is just pushed in general, but always in some particular direction(s): against, away, towards, around, down. The wind pushed Zhao away from the established signifier-signified couple and toward the potential signature coquette. She, in turn, pushed me away from my text, instituting a gap between my words and me. No longer bound to my work, I found myself blind to it. And when - after some struggle and some time - my words returned to sight, I found that Zhao's wind had pushed me away from my concern with developing a communist educational philosophy and toward pedagogical planarity. She writes about Dao De Jing, and that "what is opposite re-activates dao in movement and what is weak sustains dao in movement." The limit, the event, the feeble, and the antagonism all variously sustain and swerve the yin-yang movement. These incommensurable tendencies are not in binary opposition, but in "confrontational negotiation."

Zhao brings all of this up in response to my use of rhetorical duality in the book, a tactic I deploy to convey the force of irreducible contradictions. I wonder if this duality, this admittedly binary reasoning, can also be blocked together with the planar dao movement, such that antithesis and the heterogeneous hang beside each other in a contentious constellation? Can there be a confrontational negotiation between the binary and the variegated? Educationally speaking, can pedagogy and politics co-exist? This is a latent problematic in Communist Study, one that Zhao has brought into a sharp focus. It's something that educational theory writ large hasn't seriously considered, at least not explicitly. All too often, it seems, pedagogy is variously reduced to politics (critical pedagogy), sidelined by political analysis (critical education), or subjected to the service of politics (liberal pedagogy). In the first case, pedagogy is synonymous with political revolution, in the second case it is benched so that analyses of neoliberalism can take center field, and in the third case it is theorized and deployed with the aim of producing citizens capable of being part of a democratic order. On the other hand, radical politics makes frequent mention of pedagogy, but never in any systematic or comprehensive manner. In the fields in which I have been working - marxism, queer theory, and urban studies—I often 
encounter mentions of teaching, learning, studying, and even testing. If there is a special contribution that educational theorists and philosophers can make to contemporary political struggles, it is precisely in theorizing the relationship between pedagogy and politics, and in proposing modes of political educational engagement.

I don't think critical pedagogy or critical education are suited for the job. Both are trapped in a paranoiac state of restless agitation. We are living in end times and we lack the critical capacities to see it and to do anything about it. When I read this literature-especially on blogs-I'm reminded of Eve Sedgwick's (2003) essay, "Paranoid Reading, Reparative Reading, or, You're so Paranoid you Probably Think this Essay is About You." She questions the certain faith the critical theorists place in the act of exposure: "Like the deinstitutionalized person on the street who, betrayed and plotted against by everyone else in the city, still urges on you the fingerworn dossier bristling with his precious correspondence, paranoia for all its vaunted suspicion acts as though its work would be accomplished if only it could finally, this time, somehow get its story truly known" (p. 138). If we just keep on listing all the bad things about neoliberalism, things are bound to get better. If only our students could understand that it is really capitalism that is at fault, then the revolution will come. If only our political analysis were finally correct and known, the system would surely collapse.

In addition to an assumed ignorance of others, the critical academic exists in and insists on "a paranoid temporality... in which yesterday can't be allowed to have differed from today and tomorrow must be even more so" (p. 147). Sedgwick wants us not to abandon the critical endeavor, but to open our theoretical dispositions to the weak and affective, to the not so certain, the ambiguous, and the unpredictable. To me, this signals the need to think more deeply and carefully about both our political and pedagogical commitments. For while it would appear that political inquiry has been exhausted in education, its paranoid temporality prevents a full political appreciation of instantiations of resistance and alternative arrangements. Oppression and exploitation, they tell us, are everywhere, have been everywhere, will be everywhere. Even in the socialist camp and in countries liberated from colonialism and imperialism. Such implicit and explicit assertions are, of course, manifestly false. This adds another explanation to the anticommunism of critical pedagogy that Curry Malott (2016) has carefully demonstrated. Whereas Malott locates this anti-communism within the absence of a strong communist movement, which has left the Left fighting the specter of Stalin (p. 86), there is an affective element to it, too. We are so used to incessant critique that to consider the historically and contemporary existing alternatives to oppression and exploitation would cause us to lose our footing.

What would happen if we operated on a different footing, a footing without the solid ground of paranoia? This is, I contend, where the practice of study comes into the picture. I appreciate the way Zhao has presented and enacted studying and its figural components. Here I wish to stress that studying is an act that fractures and defamiliarizes the world as it is, instituting a time and space of suspension, apprehension, play, and possibility. And when it is organized and collective, studying can institute and hold open a rift in our world, a rift that is the possibility of political rupture. Studying is the pedagogy of the revolutionary crowds, of the insurgent collective bodies in the streets (see Ford, in press). Yet at the same time, there is no guarantee that the rift 1) persists and 2) generates something politically progressive. In fact, we have seen tragic openings that have been either shut down (Occupy) or taken in a reactionary direction (Egypt). The figural gap of study is vulnerable, which it simultaneously its hope and its danger. The point is not to guard against and foreclose this vulnerability, but neither is it to unconditionally celebrate it, as if it were a political end in itself (like the uncritical postmodern 
celebration of "otherness" that Zhao brings up). The point, rather, is to cultivate it pedagogically and direct it politically.

It is for these reasons that politics and pedagogy must exist in a confrontational negotiation. This will mean that the binary warrants a place in political educational constellations. Politics is, after all, a struggle between antagonistic forces vying for powerspecifically, the power to repress, eliminate, or at least lord over its agonists. To forget this is to disavow the possibility of making us into different subjects and our world into a different place; places and subjects that deserve each other. The pressing questions revolve around how to negotiate this confrontation, and I am happy to have fellow comrade-studiers like Zhao at the helm.

\section{References}

Ford, D.R. (2016). Communist study: Education for the commons. Lanham: Lexington Books. Ford, D.R. (in press). Studying like a communist: Affect, the Party and the educational limits to capitalism. Educational Philosophy and Theory.

Malott, C.S. (2016). History and education: Engaging the global class war. New York: Peter Lang.

Sedgwick, E.K. (2003). "Paranoid reading, reparative reading, or, you're so paranoid you probably think this essay is about you," in Touching feeling: Affect, pedagogy, performativity (pp. 123-151). Durham: Duke University Press. 